DOI: $10.34185 / 1991-7848.2018 .01 .013$

УДК 667-123

Л.А. Фролова

\title{
ВИКОРИСТАННЯ ВІДПРАЦЬОВАНИХ ТРАВИЛЬНИХ РОЗЧИНІВ ДЛЯ ВИРОБНИЦТВА ЖОВТИХ ЗАЛІЗООКСИДНИХ ПІГМЕНТІВ
}

Склад відпрацьованих травильних розчинів залежить від багатьох факторів: початковий склад розчинів, вид окалини, питома поверхня виробів, спосіб травлення та ін. Але існують деякі особливості утилізації пов'язані з присутністю органічних речовин, інгібіторів, низькими значеннями рН, змінними концентраціями солей заліза (50-500 г/дм3), присутністю нерозчинних домішок. Рідкі відходи травильних та гальванічних відділень накопичуються, а сировинна база промисловості нестримно виснажується. Тому переробка таких відходів допоможе вирішити ряд питань, серед яких виробництво більш дешевого вітчизняного продукту, який зможе конкурувати на світовому ринку з іншими виробниками. У статті розглянуто існуючі методи утилізації відпрацьованих травильних розчинів. Досліджено вплив основних чинників на процес формування залізооксидних пігментів. За допомогою рентгенофазового та мікроскопічного аналізів показані області утворення жовтого залізооксидного пігменту.

Ключові слова: гетит, травильні розчини, утилізація, синтез.

\section{Вступ}

Відпрацьовані травильні розчини (ВТР), що вміщують катіони заліза з високою концентрацією і залишкову кислоту, є небезпечними відходами процесів обробки поверхні сталі. Склад ВТР залежить від багатьох факторів: початковий склад розчинів, вид окалини, питома поверхня виробів, спосіб травлення та ін. Численні лабораторні дослідження показали, що відпрацьовані розчини від травлення чорних металів сірчаною кислотою можуть бути використані в якості сировини [1-3]. Але існують деякі особливості утилізації пов'язані з присутністю органічних речовин, інгібіторів, низькими значеннями рН, змінними концентраціями солей заліза (50-500 г/дм $\left.{ }^{3}\right)$, присутністю нерозчинних домішок.

Крім того, катіонний склад солей у ВТР при травленні легованих сталей визначається співвідношенням легуючих добавок та залежить від розчинності і складу окалини. При кислотному травленні залізо переходить в розчин у вигляді катіона заліза (II). При травленні вуглецевих сталей на катіонний склад ВТР помітно впливають домішки, які знаходяться у вихідній воді, сірчаній кислоті. У середньому кількість ВТР складає $0,1 \mathrm{~m}^{3} /$ т сталі при сірчанокислому та солянокислому травленні Рідкі відходи травильних та гальванічних відділень накопичуються, а сировинна база промисловості нестримно виснажується. Тому переробка таких відходів допоможе вирішити ряд питань, серед яких виробництво більш дешевого вітчизняного продукту, який зможе конкурувати на світовому ринку з іншими виробниками.

\section{Теоретична частина}

В останнє десятиліття для утилізації ВТР використовують новітні технології: зворотній осмос, катіонний обмін, мембранні технології, електроочищення, гідротермальний процес, електродіаліз, селективне осадження [4]. Одним із ефективних методів регенерації ВТР є екстракція. Під час екстракції водний шар після відокремлення нейтралізують таким чином, щоб в осад виділити лише гідроксиди металів. Після їх вилучення в розчині залишається сульфат натрію. Хімічний склад осаду при цьому, \%: $30 \mathrm{Fe}(\mathrm{OH})_{3} ; 40 \mathrm{CaF}_{2} ; 3 \mathrm{Cr}(\mathrm{OH})_{3} ; 5 \mathrm{Ca}\left(\mathrm{NO}_{3}\right)_{2} ; 2 \mathrm{Ni}(\mathrm{OH})_{2} ; 5 \mathrm{Ca}(\mathrm{OH})_{2} ; 14 \mathrm{H}_{2} \mathrm{O}$. Після прожарювання осад використовують як добавку до аглошихти.

Перспективним методом очищення $є$ метод іонного обміну. Особливістю іонообмінного методу $є$ необхідність регенерації іонітів з витратою реагентів і утворенням концентрованих елюатів. Іонообмінне очищення дозволяє повернути у виробництво 80-90 \% води, може використовуватися лише в тому разі, якщо вирішене питання переробки елюатів [2]. Травильні розчини широко використовуються для вилучення (переважно методом екстракції) кислот та заліза [5-7]. Також з ВТР можна селективно вилучати цинк та залізо. Розроблена технологія регенерації травильних розчинів, які мають склад (в г/л):

(C) Фролова Л.А., 2018 
$\mathrm{Fe}-137,5 ; \mathrm{Zn}-26,12 ; \mathrm{Pb}-0,091 ; \mathrm{Ni}-0.083 ; \mathrm{Cu}-0,027 ; \mathrm{Al}-0,087 ; \mathrm{HCl}-17,89$. На першому етапі селективно сорбують 3 цих розчинів $\mathrm{Zn}^{2+}$ сильноосновною аніонообмінною смолою на основі амінів. Проводять десорбцію цинку зі смоли 0,5-2,45 M HCl. Елюати направляють на отримання чистого $\mathrm{ZnCl}$. На другому етапі проводять електроосадження заліза з розчину, очищеного від цинку, при $\mathrm{pH}>1$. Електроекстракцію заліза здійснюють в електролізі з діафрагмою з аніонообмінної мембрани з регенерацією $\mathrm{HCl}$ в анодній камері [7].

Серед сучасних методів регенерації кислих травильних розчинів можна виділити групу реагентних методів. Як правило, ВТР нейтралізуються вапном, з наступним вивантаженням шламу. Однак ця технологія призводить до утворення великої кількості нестабільних шламів, які потрібно утилізувати, щоб уникнути вторинного забруднення. Через високу концентрацію заліза, використання ВТР є економічно доцільним, і може представляти собою дешеве джерело сировини для виробництва пігментів різної кольорової гами.

Наприклад, відпрацьовані кислі залізовмісні розчини обробляють відходами металообробки; в нейтралізований таким чином розчин додають осадник - розчинний фосфат за $\mathrm{pH}=6,0-8,0$ i стехіометричному співвідношенні фосфат-іонів і катіонів металу, та відокремлюють отриманий осад. Фільтрат може бути повернутий у виробництво. Спосіб дозволяє досить повно видаляти іони заліза 3 перероблених розчинів і використовувати надалі тверді осади, що утворюються, як пігментні пасти [8].

Однак, у теперішній час важливим $є$ використання технологій, що дають змогу отримувати високоякісні продукти.

На сучасному ринку особливим попитом користується жовтий залізооксидний пігмент - гетит. Використання травильних розчинів в якості вихідної сировини дозволяє значно зменшити вартість кінцевого продукту.

Метою даної роботи є дослідження реагентного методу утилізації ВТР для одержання жовтого залізооксидного пігменту в системі $\mathrm{Fe}^{2+} / \mathrm{SO}_{4}^{2-} / \mathrm{OH}^{-} / \mathrm{O}_{2}$, побудова діаграм фазового стану, визначення областей утворення гетиту.

\section{Методика проведення експериментів}

Для реагентної утилізації ВТР використовували каустичну соду. Досліджували два режими. Перший - режим нейтралізації одноразовим додаванням лугу до заданого значення $\mathrm{pH}$, або підтриманням значення $\mathrm{pH}$ на постійному рівні безперервним додаванням невеликих порцій лугу. Після додавання лугу в процесі гідролізу і формування продуктів рН знижується (рН-динамічний режим). У другому випадку величина $\mathrm{pH}$ коливається протягом всього процесу близько заданого значення (рН-статичний режим). Використовували травильні розчини концентрацією $0,5 \mathrm{M}$ сульфату заліза (II). Як окислюючий агент використовували повітря, ефективна швидкість подачі якого становила 4-12 хв ${ }^{-1}$.Концентрацію катіонів заліза в розчині визначали титриметричним методом [9].

Рентгенограми оксигідроксидів і оксидів, а також металевих порошків визначали на дифрактометрі ДРОН -2.0 з Со-К в випромінюванням.

Розміри частинок порошків оксигідроксида заліза, оксидів, а також металевих порошків визначали методом просвічуючої мікроскопії за допомогою електронного мікроскопа ЕMB-125.

\section{Результати досліджень та їх обговорення}

Технологія одержання жовтих залізооксидних пігментів шляхом осадження каустичною содою з наступним окисненням киснем повітря включає наступні стадії:

-очищення відпрацьованих травильних розчинів від зважених частинок шляхом відстоювання та фільтрування;

-корегування концентрації сульфату заліза до 0,5 M;

-осадження каустичною содою до відповідного рН;

-нагрівання суспензії;

-окислення отриманої суспензії;

-фільтрування, промивання і сушіння осаду.

Однак основними є стадії утворення гідроксиду заліза (II) та окиснення до тривалентного оксигідроксиду. Оскільки фазовий і дисперсний склад оксидних сполук заліза залежать від багатьох 
чинників: величини $\mathrm{pH}$ розчину солі заліза (II) або суспензії $\mathrm{Fe}(\mathrm{OH})_{2}$, температури реакційної середовища, швидкості подачі повітря, необхідно вивчення їх впливу в системі $\mathrm{Fe}^{2+} / \mathrm{SO}_{4}{ }^{2-} / \mathrm{OH}^{-} / \mathrm{O}_{2}$.

В ході дослідження необхідно було встановлення основних тенденцій зміни фазового $\mathrm{i}$ дисперсійного складу твердої фази від умов синтезу. Існування значної кількості сполук заліза різного ступеня окиснення значно ускладнює процес синтезу і потребує чіткого дотримання режиму проведення процесу [10,11].

Проведені дослідження процесу i продуктів окислення системи $\mathrm{Fe}^{2+} / \mathrm{SO}_{4}{ }^{2-} / \mathrm{OH}^{-} / \mathrm{O}_{2}$ при фіксованій швидкості подачі повітря, температурі і змінної величині $\mathrm{pH}$ суспензії показують, що фазовий склад одержуваного продукту в значній мірі залежить від рН розчину (рис.1а, 1б).

Аналіз рис. 1 і рис. 2 свідчить про те, що в $\mathrm{pH-статичному} \mathrm{режимі} \mathrm{діапазон} \mathrm{отримання} \mathrm{гетиту}$ значно ширший, ніж в $\mathrm{pH}$ - динамічному режимі, тому подальші експериментальні дослідження проводилися при рН-статичному режимі.

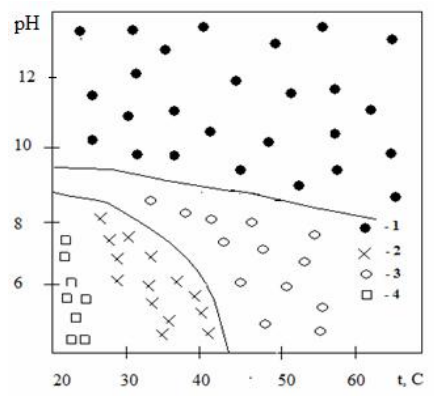

a)

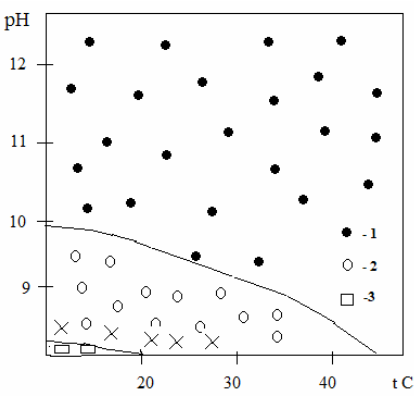

б)

Рисунок 1 - Залежність фазового складу отриманого осаду в системі $\mathrm{Fe}^{2+} / \mathrm{SO}_{4}^{2-} / \mathrm{OH}^{-} / \mathrm{O}_{2}$, від температури та pH розчина в рН статичному режимі (a): $1-\mathrm{Fe}_{3} \mathrm{O}_{4}, 2-\alpha-\mathrm{FeOOH}, 3-\alpha-\mathrm{FeOOH}+\mathrm{Fe}_{3} \mathrm{O}_{4}$, $4-\gamma-\mathrm{FeOOH}$ в $\mathrm{pH}$ - динамічному режимі

(б): 1 - $\mathrm{Fe}_{3} \mathrm{O}_{4} ; 2$ - $\alpha$ - FeOOH, 3- $\gamma$ - FеOOH; (швидкість подачі повітря $10 \mathrm{xв}^{-1}$ )

Зі збільшенням $\mathrm{pH}$ від 6 до 10 при однакових параметрах синтезу реєструється така послідовність фазоутворення: $\gamma-\mathrm{FeOOH}-\alpha-\mathrm{FeOOH}-\mathrm{Fe}_{3} \mathrm{O}_{4}+\alpha-\mathrm{FeOOH}$. При подальшому збільшенні $\mathrm{pH}$ розчину утворюється $\mathrm{Fe}_{3} \mathrm{O}_{4}$. Утворення магнетиту при високих значеннях $\mathrm{pH}$ обумовлено низькою швидкістю окиснення, що дає змогу перебудові у шпінельну структуру, низькі значення рН сприяють утворенню лепідокрокіту та гетиту.

Для з'ясування закономірностей зміни фазового складу одержуваних оксидних сполук заліза при зміні температури і швидкості подачі повітря проведені дослідження процесу і продуктів окислення гідроксиду заліза (II) (pH=6-12) в інтервалі температур (20-60 드) і швидкості подачі повітря (4-12 хв $\left.{ }^{-1}\right)$.

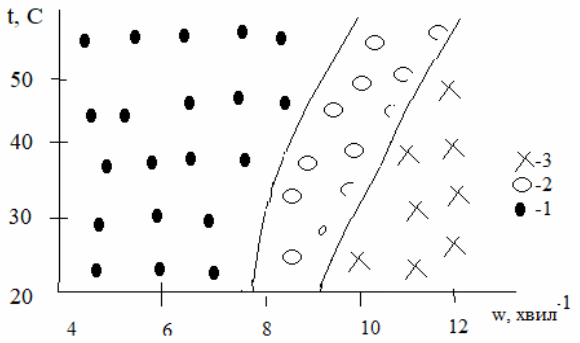

Рисунок 2 - Залежність фазового складу одержуваного осаду в системі $\mathrm{Fe}^{2+} / \mathrm{SO}_{4}{ }^{2-} / \mathrm{OH}^{-} / \mathrm{O}_{2}$ від температури і швидкості подачі повітря $1-\mathrm{Fe}_{3} \mathrm{O}_{4}, 2-\alpha-\mathrm{FeOOH}+\mathrm{Fe}_{3} \mathrm{O}_{4}, 3-\alpha-\mathrm{FeOOH}$

Швидкість змінювали шляхом дозування повітря, а закінчення процесу визначали за даними зміни окислювально-відновного потенціалу системи і часу окислення до досягнення потенціалу постійного значення. 3'ясовано, що кінцевим продуктом окислення гідроксиду заліза (II) в залежності від параметрів синтезу можуть бути оксигідроксид заліза (III) $\alpha$ - модифікації, змішаний оксид заліза (II) i (III) або бінарна суміш $\alpha-\mathrm{FeOOH} \mathrm{i} \mathrm{Fe}_{3} \mathrm{O}_{4}$.

За даними залежності фазового складу продуктів, що утворюються при окисленні гідроксиду заліза (II), від параметрів синтезу побудована діаграма системи (рис. 2), на якій в координатах температура - швидкість подачі повітря відображені області переважного утворення кожної з фаз. 
Оскільки цільовим продуктом $\epsilon \alpha-\mathrm{FeOOH}$, то оптимальними умовами $\epsilon$ температура $30-40{ }^{\circ} \mathrm{C}$ i ефективна швидкість подачі повітря не менше 10-12 хв- ${ }^{1}$. Дані ренгенофазового та мікроскопічного аналізу приведені на рисунку 3,4. Порівняння положень піків картотеки рентгенограм JCPDS з одержаним зразком, показали, що синтезована сполука - гетит (рис.3). Значне розширення дифракційних піків свідчить про те, що гетит нанодисперсний. Мікроскопічний аналіз підтвердив, що гетит має голчасту форму, формфактор 7-10.

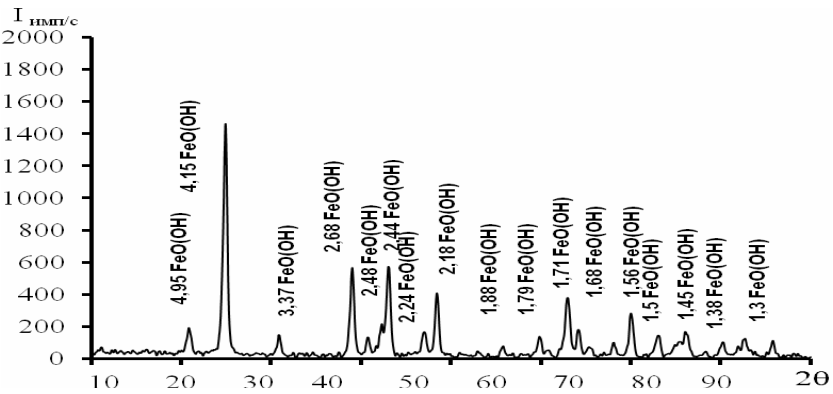

Рисунок 3 - Рентгенограма $\alpha$ - оксигідроксиду заліза

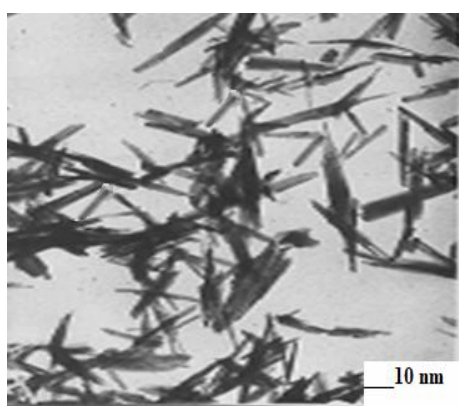

Рисунок 4 - Мікрофографія $\alpha$ - оксигідроксиду заліза

\section{Висновок}

1. Експериментальні дані показують, що зі збільшенням температури і швидкості подачі повітря зменшується час окислення. Однак, за даними рентгенівського дослідження за температури $20-45{ }^{\circ} \mathrm{C} \mathrm{pH} \mathrm{7-9} \mathrm{утворюється} \mathrm{гетит.}$

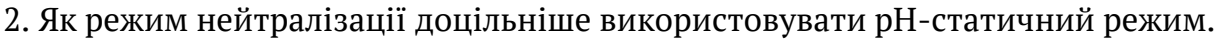

3. У $\mathrm{pH}$-статичному режимі діапазон отримання гетиту (відповідних виходу 98\%) значно ширший, ніж в рН - динамічному режимі;

4. Діаграми фазового складу одержуваного осаду в системі $\mathrm{Fe}^{2+} / \mathrm{SO}_{4}{ }^{2-} / \mathrm{OH}^{-} / \mathrm{O}_{2}$, від температури i швидкості подачі повітря показують, що оптимальними умовами $\epsilon$ температура $30-40{ }^{\circ} \mathrm{C}$ i ефективна швидкість подачі повітря не менше 10-12 $\mathrm{xB}^{-1}$.

\section{ЛITЕРАТУРА}

1. Добровольский, И.П., Технологии переработки отходов / И.П. Добровольский, Н.А. Плохих. Челябинск, 2005. - 219 c.

2. Вайнштейн, И.А. Очистка и использование сточных вод травильных / И.А. Вайнштейн - М.: Металлургия, 1958. - 110 с.

3. Han, H., Sun, W., Hu, Y., Cao, X., Tang, H., Liu, R., \& Yue, T. Magnetite precipitation for iron removal from nickel-rich solutions in hydrometallurgy process //Hydrometallurgy. - 2016. - T. 165. - C. 318-322.

4. Regel-Rosocka, M. A review on methods of regeneration of spent pickling solutions from steel processing / M. RegelRosocka. //Journal of Hazardous Materials. - 2010. - T. 177. - №. 1-3. - C. 57-69.

5. Agrawal, A. Extraction of acid and iron values from sulphate waste pickle liquor of a steel industry by solvent extraction route / A. Agrawal, S. Kumari, B.C. Ray, K.K. Sahu // Hydrometallurgy. - 2007. - № 1-4. - C.58-66.

6. Вошкин, А.А. Экстракция железа из травильных хлоридных растворов / А.А. Вошкин, В.В. Белова, А.И. Холькин, А. Агравал // Химическая технология - 2003. - № 11. - С.28-32.

7.Csicsovski, G. Selective recovery of $\mathrm{Zn}$ and Fe from spent pickilling solutions by the combination of anion exchange and membrane electrowinning techiques / G. Csicsovski, T. Kekesi, T.I. Torok // Hydrometallurgy. 2005. - № 1-2. - C.19-28.

8. Пат. 2110488 Российская Федерация, МПК C02F1/64. Способ утилизации кисльх железосодержащих растворов / Рослякова Н.Г., Конорев Б.П., Росляков А.О., Росляков Р.О. (Российская Федерация); заявитель и патентообладатель Рослякова Н.Г., Конорев Б.П. - № 96112022/25; заявл. 17.06.1996; опубл. 10.05.1998, Бюл. № 4. - 3 с

9. Алексеев, В.Н. Количественный анализ / В.Н. Алексеев - М.: Химия, 1972. - 504 с.

10. Радовенчик B.М. Окисление Fе(II) кислородом воздуха для получения суспензии магнетита: Обзор / В.М. Радовенчик, Е.И. Иваненко // Экотехнологии и ресурсосбережение. - 2001. - № 5. - С. 37-48.

11. Шабанова, Н.А. Химия и технология нанодисперсных оксидов / Н.А. Шабанова, А.А. Попов, П.Д. Саркисов. - М.: Академкнига. 2007. - 297 с. 


\section{REFERENCES}

1. Dobrovolskiy, I.P., Tehnologii pererabotki othodov / I.P. Dobrovolskiy, N.A. Plohih. Chelyabinsk, 2005. - $219 \mathrm{~s}$. 2. Vaynshteyn, I.A. Ochistka i ispolzovanie stochnyih vod travilnyih/ I.A. Vaynshteyn - M.: Metallurgiya, 1958. - $110 \mathrm{~s}$.

3. Han, H., Sun, W., Hu, Y., Cao, X., Tang, H., Liu, R., \& Yue, T. Magnetite precipitation for iron removal from nickel-rich solutions in hydrometallurgy process //Hydrometallurgy. - 2016. - T. 165. - S. 318-322.

4. Regel-Rosocka, M. A review on methods of regeneration of spent pickling solutions from steel processing / M. RegelRosocka. //Journal of Hazardous Materials. - 2010. - T. 177. - \#. 1-3. - S. 57-69.

5. Agrawal, A. Extraction of acid and iron values from sulphate waste pickle liquor of a steel industry by solvent extraction route / A. Agrawal, S. Kumari, B.C. Ray, K.K. Sahu // Hydrometallurgy. - 2007. - \# 1-4. - S.58-66.

6. Voshkin, A.A. Ekstraktsiya zheleza iz travilnyih hloridnyih rastvorov / A.A. Voshkin, V.V. Belova, A.I. Holkin, A. Agraval // Himicheskaya tehnologiya - 2003. - \# 11. - S.28-32.

7.Csicsovski, G. Selective recovery of $\mathrm{Zn}$ and Fe from spent pickilling solutions by the combination of anion exchange and membrane electrowinning techiques / G. Csicsovski, T. Kekesi, T.I. Torok // Hydrometallurgy. 2005. - \# 1-2. - S.19-28.

8. Pat. 2110488 Rossiyskaya Federatsiya, MPK C02F1/64. Sposob utilizatsii kislyih zhelezosoderzhaschih rastvorov / Roslyakova N.G., Konorev B.P., Roslyakov A.O., Roslyakov R.O. (Rossiyskaya Federatsiya); zayavitel i patentoobladatel Roslyakova N.G., Konorev B.P. - \# 96112022/25; zayavl. 17.06.1996; opubl. 10.05.1998, Byul. \# 4. - 3 s

9. Alekseev, V.N. Kolichestvennyiy analiz / V.N. Alekseev - M.: Himiya, 1972. - 504 s.

10. Radovenchik V.M. Okislenie Fe(II) kislorodom vozduha dlya polucheniya suspenzii magnetita: Obzor / V.M. Radovenchik, E.I. Ivanenko //Ekotehnologii i resursosberezhenie. - 2001. - \# 5. - S. 37-48.

11. Shabanova, N.A. Himiya i tehnologiya nanodispersnyih oksidov / N.A. Shabanova, A.A. Popov, P.D. Sarkisov. - M.: Akademkniga. 2007. - 297 s.

\section{USING OF SPENT ETCHING SOLUTION TO OBTAIN YELLOW FERRIC OXIDE PIGMENTS}

Received 30.01.18

The composition of spent pickling solutions depends on many factors: the initial composition of the solutions, the type of scale, the specific surface of the products, the method of etching, etc. But there are some utilization features associated with the presence of organic substances, inhibitors, low $\mathrm{pH}$ values, interchangeable concentrations of iron salts (50-500 g/ dm3), the presence of insoluble impurities. Liquid wastes from pickling and electroplating departments accumulate, and the raw material base of industry is rapidly depleting. Therefore, the processing of such waste will help solve a number of issues, including the production of a cheaper domestic product that can compete on the world market with other manufacturers. The article discusses the existing methods of disposal of waste pickling solutions. The influence of the main factors on the formation of mineralized oxygene pigments was studied. With the help of X-ray and microscopic analyzes, areas of formation of a yellow mineralized oxide pigment are shown.

Keywords: goethite, etching solutions, utilization, synthesis.

\section{ИСПОЛЬЗОВАНИЕ ОТРАБОТАННЫХ ТРАВИЛЬНЫХ ДЛЯ ПОЛУЧЕНИЯ ЖЕЛТЫХ ЖЕЛЕЗООКСИДНЫХ ПИГМЕНТОВ}

Состав отработанных травильных растворов зависит от многих факторов: начальный состав растворов, вид окалины, удельная поверхность изделий, способ травления и др. Но существуют некоторые особенности утилизации связанные с присутствием органических веществ, ингибиторов, низкими значениями $\mathrm{pH}$, сменными концентрациями солей железа (50-500 г / дм3), присутствием нерастворимых примесей. Жидкие отходы травильных и гальванических отделений накапливаются, а сырьевая база промышленности стремительно истощается. Поэтому переработка таких отходов поможет решить ряд вопросов, среди которых производство более дешевого отечественного продукта, который сможет конкурировать на мировом рынке с другими производителями. В статье рассмотрены существующие методы утилизации отработанных травильных растворов. Исследовано влияние основных факторов на процесс формирования зализооксидних пигментов. С помощью рентгенофазового и микроскопического анализов показаны области образования желтого зализооксидного пигмента.

Ключевые слова: гетит, травильные растворы, утилизация, синтез.

Фролова Лілія Анатоліївна - к.т.н., доцент, кафедри ТНРтаЕ, ДВНЗ «Український державний хіміко-технологічний університет».

Frolova Liliya - Candidate of Technical Sciences, Associate Professor, Department of TNRtaE, Ukrainian State Chemical-Technological University. 